\title{
1 THESSALONIANS 2:14-16 AND THE CHURCH IN JERUSALEM
}

\author{
Markus Bockmuehl
}

\begin{abstract}
Summary
Decades of interpretative controversy have failed to provide a satisfactory explanation of what Judaean events, if any, might have occasioned St Paul's bitter invective in 1 Thessalonians 2:14-16. After re-examining the familiar arguments by B.A. Pearson and others for a non-Pauline interpolation, this study questions the widespread assumption that Jewish persecution of Christians cannot be substantiated prior to the first Jewish War. Rehearsing the evidence for hostile measures against Jewish believers c. AD 36 and again under Agrippa I in 41/42, the argument turns to the neglected suggestion by the sixth-century chronicler Malalas of Antioch that a further persecution of the Jerusalem church took place in the eighth year of Claudius' (AD 48/49). Such a course of events during the notorious procuratorship of Ventidius Cumanus would shed light not only on 1 Thessalonians 2, but possibly also on the setting of Galatians. In any case, both Josephus and rabbinic literature indicate that the death of Agrippa I was widely perceived as the beginning of a disastrous downturn in Jewish fortunes, to which Paul may be alluding in v. 17. Ironically, a number of these points were familiar to scholars in the $18^{\text {th }}$ and $19^{\text {th }}$ centuries, but seem since then to have been forgotten.
\end{abstract}

\section{Introduction}

St. Paul's intemperate outburst against 'the Jews' in 1 Thessalonians 2:14-16 has long troubled the politically reconstructed, postHolocaust guild of Neutestamentler. How can the same man possibly have believed that God's wrath and definitive condemnation have 'finally come upon' the Jews - only to claim elsewhere that 'all Israel will be saved'? He cannot possibly have meant it, argue wellintentioned traditional scholars. No, he cannot possibly even have said it, responds another group, who over the last quarter-century seem for 
a while to have enjoyed the advantage of scholarly momentum. ${ }^{1}$ For others still, the fact that Paul both said it and meant it just goes to show that Christianity was irretrievably racist and anti-Jewish from its very foundation. As is the case for certain other famous interpretative conundrums, such diversity of opinion may here be more indicative of exegetes' hermeneutical predilections than of the exegetically likely range of meanings.

Is it possible to shed any light on this question? Like so many overcrowded fields of New Testament study, our passage does not permit of comprehensive treatment within a single article. ${ }^{2}$ Among other important questions that must be left for another discussion is the whole Thessalonian context of the passage: what are the circumstances in Thessalonica that make an appeal to the Judaean

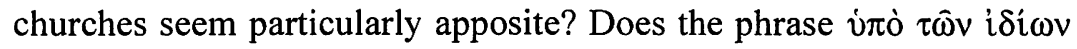
$\sigma v \mu \phi v \lambda \varepsilon \tau \hat{\omega} v$ imply that the Thessalonian persecutors were primarily pagan, primarily Jewish, or perhaps the sort of mixed mob envisaged in Acts 17:5?3 And so on.

I It was of course F.C. Baur who adopted the most consistent position in taking seriously not only the ideological premise but also the text-critical evidence. He was thus led to conclude that, because Paul could not have written 1 Thes. 2:14-16, the rest of the letter must be pseudonymous too. Several of his students followed him. See F.C. Baur, Paul, the Apostle of Jesus Christ, His Life and Work, His Epistles and His Doctrine (ET of 2nd ed. E. Zeller; London: Williams \& Norgate, $1875-76 ; 2$ vols), 2.87-88 and cf. the remarks of E. von Dobschütz, Die Thessalonicher-Briefe (KEKNT 10; 7th edn.; Göttingen: Vandenhoeck \& Ruprecht, 1909), 31-32. On the issue of authenticity see further below.

2 Partial surveys of the literature are offered in R.F. Collins, Studies on the First Letter to the Thessalonians (BETL 66; Leuven: University Press, 1984); C.J. Schlueter, Filling up the Measure: Polemical Hyperbole in 1 Thessalonians 2:1416 (JSNTS 98; Sheffield: JSOT, 1994); J.A.D. Weima \& S.E. Porter, An Annotated Bibliography of 1 and 2 Thessalonians (NTTS 26; Leiden: Brill, 1998); see also the major commentaries: Dobschütz, Die Thessalonicher-Briefe; B. Rigaux, Saint Paul: Les épîtres aux Thessaloniciens (EB; Paris: Lecoffre, 1956); F.F. Bruce, 1 \& 2 Thessalonians (WBC 45; Waco: Word, 1982); T. Holtz, Der erste Brief an die Thessalonicher (EKKNT 13; Zurich: Benziger, 1986); C.A. Wanamaker, The Epistles to the Thessalonians: A Commentary on the Greek Text (NIGTC; Grand Rapids: Eerdmans, 1990).

3 Cf. further C.K. Barrett, A Critical and Exegetical Commentary on the Acts of the Apostles (ICC; Edinburgh: T. \& T. Clark, 1998), 2.813-14. For the Thessalonian dimension of conflict with $\sigma v \mu \phi v \lambda \varepsilon \tau \alpha$ i, see e.g. J.M.G. Barclay, 'Conflict in Thessalonica', $C B Q 55$ (1993), 512-30 (he plausibly argues for Gentiles, p. 514; cf. B.A. Pearson, ' 1 Thessalonians 2:13-16: A Deutero-Pauline Interpolation', HTR 64 (1971), 79-94, p. 86 with appeal to Theodore of Mopsuestia) and more recently T.D. Still, Conflict at Thessalonica: A Pauline Church and Its Neighbours (JSNTS 183; Sheffield: Sheffield Academic, 1999), 208-86 and C.S. De Vos, Church and Community Conflicts : The Relationships of the Thessalonian, Corinthian, and Philippian Churches with Their Wider Civic Communities (SBLDS 168; Atlanta: Scholars, 1999), 123-77 (esp. 155-68); cf. 
Here, however, our study will be confined to one relatively modest issue: if Paul's appeal to the example of the Judaean churches is authentic, what can be known of its likely historical occasion? After addressing a few introductory questions surrounding the integrity and the date of our text, we shall attempt to expound the likely experiences of the Judaean Christians that may have occasioned and coloured Paul's remarks.

\section{Literary Integrity, Authenticity and Date}

\section{a) 1 Thessalonians as a Whole}

The letter's Pauline authorship is not normally in doubt; but the integrity and authenticity of 1 Thessalonians 2:14-16 continue to be heavily disputed, even among scholars who are not usually given to hypotheses of compilation or interpolation. While our main interest here is to ask about the historical locus of the passage, if indeed it is authentic, in the current state of Pauline scholarship even that working assumption require a certain amount of justification.

To simplify our task, I wish here to touch only briefly on the discussion of whether 1 Thessalonians as a whole is compiled out of two or more letter fragments. This view was most famously proposed by Walter Schmithals and endorsed in various forms by a number of other scholars, including recently Earl J. Richard and Jerome MurphyO'Connor (the latter concluding with characteristic confidence that his is the 'only' possible solution $\left.{ }^{4}\right)$. On purely formal grounds, it is certainly true that 1 Thessalonians would appear to contain either one extraordinarily long introductory thanksgiving extending from 1:2 perhaps all the way to $3: 13,5$ or else two introductory thanksgivings $(1: 2-10 ; 2: 13[-16]) \cdot{ }^{6}$ Some also profess to find two conclusions, viz.

also, more speculatively, R. Jewett, The Thessalonian Correspondence: Pauline Rhetoric and Millenarian Piety (Philadelphia: Fortress, 1986), 161-78.

4 J. Murphy-O'Connor, Paul: A Critical Life, (Oxford: OUP, 1996), 105.

5 So classically P. Schubert, Form and Function of the Pauline Thanksgivings, (Berlin: Töpelmann, 1939), 16-27, followed by Jewett, The Thessalonian Correspondence, 34; similarly P.T. O'Brien, Introductory Thanksgivings in the Letters of Paul (NovTSup 49; Leiden: Brill, 1977), 144; J. Lambrecht, 'Thanksgivings in 1 Thessalonians 1-3', in The Thessalonian Correspondence (BETL 87; Louvain: University Press, 1990), 183-205, at pp. 185-94.

6 So e.g. Murphy-O'Connor, Paul: A Critical Life, 105, citing W. Schmithals, 'Die Thessalonicherbriefe als Briefkompositionen', in Zeit und Geschichte: 
$3: 11-4: 2$ and $5: 23-28,7$ and to see a number of contradictory statements that would make better sense if assigned to different letters. ${ }^{8}$

Aside from the problem of the introductory thanksgiving, however, most of the arguments for compilation are less than persuasive. The supposed contradictions seem to be largely in the eye of the beholder; and the fact that Paul, like Beethoven, takes a long time to finish his composition is not without parallel in his other letters. ${ }^{9}$ The thanksgiving itself is an untidy matter on any reckoning, and perhaps just goes to illustrate the extent to which Paul's letters do not readily conform to a neatly defined form-critical or rhetorical pattern. (It is worth remembering that Galatians has no thanksgiving at all, and that 2 Thessalonians, which Murphy-O'Connor regards as 'more at home in the Pauline corpus than 1 Thessalonians or 1 Corinthians', ${ }^{10}$ also has two: $1: 3-10 ; 2: 13-14)$. As perhaps the earliest two surviving letters, Galatians and 1 Thessalonians may in fact both represent what Helmut Koester has called 'an experiment in Christian writing'.11 That is to say, they are ad hoc documents written well before the emergence of any formally and rhetorically defined genre of Christian epistolography. 12

Dankesgabe an Rudolf Bultmann zum 80. Geburtstag, ed. E. Dinkler (Tübingen: Mohr Siebeck, 1964), 295-315 at p. 298.

7 So Murphy-O'Connor, Paul: A Critical Life, 105, who again cites Schmithals, 'Die Thessalonicherbriefe als Briefkompositionen'; cf. E. Richard, First and Second Thessalonians (SP 11; Collegeville: Liturgical, 1995), 11-12.

8 Richard, First and Second Thessalonians, 11, for example, contrasts 2:17 (assuming Paul's relatively recent departure) with 1:6-7 (which could be taken to suggest that more time has elapsed); but none of his examples seem particularly cogent.

9 Notably in Philippians: see e.g. M. Bockmuehl, A Commentary on the Epistle to the Philippians (BNTC; London: A. \& C. Black, 1997), 174-77, 255.

10 Murphy-O'Connor, Paul: A Critical Life, 111.

11 H. Koester, 'I Thessalonians: Experiment in Christian Writing', in Continuity and Discontinuity in Church History: Essays Presented to George Huntston Williams, eds. F.F. Church \& T. George, (SHCT 19; Leiden: Brill, 1979), 31-44.

12 Note especially C.J. Classen, 'St Paul's Epistles and Ancient Greek and Roman Rhetoric', in Rhetoric and the New Testament: Essays from the 1992 Heidelberg Conference, eds. S.E. Porter \& T.H. Olbricht (JSNTS 90; Sheffield: JSOT, 1993), 265-91; cf. M. Hengel \& A.M. Schwemer, Paul between Damascus and Antioch: The Unknown Years, (London: SCM, 1997), 3-4 and n.14; also Still, Conflict at Thessalonica, 29. There has in fact been no lack of contrary attempts to use arguments from text-linguistic and rhetorical criticism to justify the integrity of 1 Thes.: see e.g. B.C. Johanson, To All the Brethren: A Text-linguistic and Rhetorical Approach to I Thessalonians (CBNT 16; Stockholm: Almquist \& Wiksell, 1987), 96-99; P. Wick, 'Ist I Thess 2,13-16 antijüdisch: Der rhetorische Gesamtzusammenhang des Briefes als Interpretationshilfe für eine einzelne 
It seems fair to conclude that none of the various compilation proposals have managed to garner sufficient support. Indeed, the unity of the document as a whole continues to be ably and sanely defended by scholars from a broad spectrum of opinion. 13

\section{b) 1 Thessalonians 2:14-16: The Case for Interpolation}

On the authenticity of 2:14-16, by contrast, New Testament scholarship still seems to be at some remove from a clear consensus. Throughout the past century, a significant body of critical opinion held to the view that these verses must be an interpolation. ${ }^{14}$ The arguments in this respect are essentially of two kinds: literary and ideological. Our main purpose here is not to cut this particular Gordian knot once for all. For this reason, it may suffice briefly to rehearse the main issues as they have been classically presented by Birger Pearson, whose 1971 article both advocates and critics of the interpolation theory continue to cite as definitive. ${ }^{15}$

Professor Pearson takes his cue from the striking claim in v. 16 that in response to Jewish persecution God's 'wrath has overtaken them at last' (NRSV). This phrase, of course, has long been suspected as an interpolation. ${ }^{16}$ The clue to Pearson's understanding of this text is to

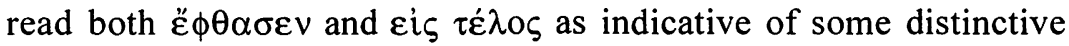
past event of catastrophic finality. In his view, such language could be appropriately applied to only one first-century situation, which is the

Perikope', TZ 50.1 (1994), 9-23. For the possible early date of Galatians see also n. 85 below.

13 See e.g. Collins, Studies on the First Letter to the Thessalonians, 114-24; Jewett, The Thessalonian Correspondence, 31-46; D.A. Carson et al., An Introduction to the New Testament (Grand Rapids: Zondervan, 1992), 353-55; R. Riesner, Paul's Early Period: Chronology, Mission Strategy, Theology, trans. D. Stott (Grand Rapids: Eerdmans, 1998), 404-11. R.E. Brown's assessment of scholarly opinion is that 'unity is overwhelmingly asserted' (An Introduction to the New Testament (New York: Doubleday, 1997), 457).

14 For the earlier scholarship see Dobschütz, Die Thessalonicher-Briefe, 32 n.3 and Collins, Studies on the First Letter to the Thessalonians.

15 Pearson, ' 1 Thessalonians 2:13-16: A Deutero-Pauline Interpolation' [henceforth: 'Interpolation']; other key proponents since then have included $\mathrm{H}$. Boers, 'Form critical study of Paul's letters: I Thessalonians as a case study', NTS 22 (1976), 140-58, D. Schmidt, '1 Thess 2:13-16: Linguistic Evidence for an Interpolation', JBL 102 (1983), 269-79 and recently Richard, First and Second Thessalonians, 17-19.

16 It is missing from certain manuscripts of the Vulgate; the apparatus of NestleAland ${ }^{27}$ includes $\mathrm{H}$. Rodrigues and $\mathrm{A}$. Ritschl as early conjecturers in this regard. Note, however, the corrective offered by T. Baarda, " 1 Thess. 2:14-16: Rodrigues in "Nestle-Aland", NedTTs 39 (1985), 186-93. For the early history of research see further Schlueter, Filling up the Measure, 13-24. 
destruction of Jerusalem in AD 70.17 Since v. $16 \mathrm{c}$ also shows close participial links with verses $16 \mathrm{a}-\mathrm{b}$ and 15 and back to v. 14, all of 1316 must therefore belong together as the likely product of a post-70 glossator, whose marginal note a subsequent copyist then included in the text.

Following on this opening exposé, Pearson proceeds to list additional historical and theological observations to strengthen his hypothesis. He finds in the language of verses 15-16 material evidence of the sort of anti-Judaism that is typical of contemporary Graeco-Roman attitudes, but which one could not imagine a Jew even of Paul's pro-Gentile convictions to have uttered. It is indeed one of the unusual features of verse 15 that Paul nowhere else subscribes to the simplistic view that holds 'the Jews' responsible for the death of

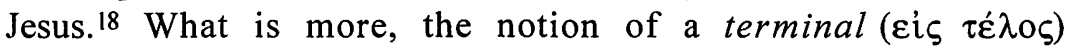
condemnation of the Jews seems to Pearson ${ }^{19}$ to be in direct contradiction to Paul's stance in Romans 9-11.

Turning to the assertion of a Jewish persecution of Christians in Judaea, Pearson denies that there is either New Testament or any other evidence of such activity between the time of Agrippa I (AD 4144) and the outbreak of the Jewish War. ${ }^{20}$

Two further observations supplement Professor Pearson's case. He notes that, in contrast to 2:14, Paul elsewhere exhorts his churches to imitate no one other than Christ and himself. And secondly, Pearson underlines the extent to which verses 13-16 interrupt the logical flow of thought between 2:11-12 and 2:17, which on form-critical grounds he regards as a unit concerned with the 'apostolic parousia'.

In his conclusion (91-94), Pearson proposes that the interpolator recycled elements of the introductory thanksgiving in 1:2-10 in his Pauline-sounding frame. This could then accommodate his message of encouragement uniting persecuted Gentile and Jewish Christians against the increasingly antagonistic Judaism of the post-70 period.

17 Pearson, 'Interpolation', 81-83; cf. earlier interpreters cited in S. Légasse, 'Paul et les Juifs d'après 1 Thessaloniciens 2,13-16', $R B 104$ (1997), 572-91, 586 n.53.

18 A familiar point, recently rephrased and refined by Légasse, 'Paul et les Juifs d'après 1 Thessaloniciens 2,13-16', 579 ('Paul est cependant le premier à attester l'attribution de la mort de Jésus aux Juifs sans plus'). He suspects that the idea, similarly employed in Acts and John, may in fact take its origin from the primitive Christian kerygma.

19 As F.C. Baur before him (cf. Pearson, 'Interpolation', 80), and others since.

20 'Interpolation', 86. 


\section{c) 1 Thessalonians 2:14-16: Evaluating the Case for Interpolation}

The attractive case espoused (and quite recently reaffirmed ${ }^{21}$ ) by Pearson has been highly influential, being endorsed in varying forms by a substantial minority of writers on 1 Thessalonians.22 Nevertheless, several of its premises seem to rest on dubious foundations.

As in all such cases, it is appropriate to sound a familiar, but by no means perfunctory, note of caution. The well-known tenacity of the New Testament's textual transmission invariably places the burden of proof on the advocates of unattested variants. ${ }^{23}$ In particular, one can adopt a textually unsupported interpolation theory only as a very last resort, after alternative explanations have been exhausted. This rule is particularly apposite in the present case. Since there is not a shred of external evidence, one must imagine the putative post-70 glossator to have successfully duped the entire textual and interpretative tradition-and this despite the fact that he worked at least a quartercentury after Paul, at which point other copies of the letter must have existed.

With this in mind, we may turn to Pearson's substantive

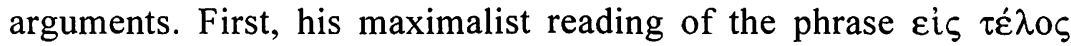
seems to be an unnecessary over-interpretation. Neither a final eschatological condemnation of the Jews nor some other catastrophic event (cf. 'to the uttermost' in AV and other older translations) is required by this phrase. In rendering these two words 'at last', RSV and NRSV are right to find here, as in Luke 18:5, an adverbial phrase carrying somewhat more modest temporal connotations. ${ }^{24}$

As for $\ddot{\varepsilon} \phi \theta \alpha \sigma \varepsilon v$, any interpretation of this morpheme must also bear in mind its distinctive early Christian usage as evidenced in

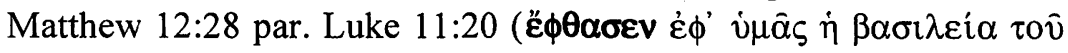
$\theta \varepsilon \circ \hat{v})$, along with its parallel in Mark 1:15 par. Matthew 4:16

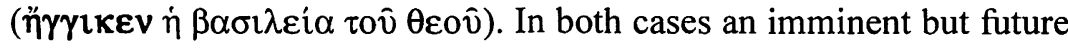

21 It was republished in B.A. Pearson, The Emergence of the Christian Religion: Essays on Early Christianity (Harrisburg: TPI, 1997), 58-74.

22 See the writers cited earlier; cf. e.g. the interesting comment in D. Georgi, Remembering the Poor: The History of Paul's Collection for Jerusalem (Nashville: Abingdon, 1992), $x$, who explains the omission of 1 Thes. 2:14-16 from the second (English) edition of his book on Paul's collection 'after Birger Pearson decisively changed my mind regarding its authenticity'. Similarly cf. Boers, 'Form critical study of Paul's letters', 152.

23 See n. 58 below, and cf. W.O. Walker, Jr., 'The Burden of Proof in Identifying Interpolations in the Pauline Letters', NTS 33 (1987), 610-18.

24 Cf. also Gn. 46:4 LXX; 2 Mac. 8:29; Sir. 12:11. 
event is foreshadowed and inaugurated in the present. Leaving aside this important question of Christian usage, Pearson is almost certainly right to see here at least in part a reference to an identifiable past event, even if one must allow for a less precise, and quite possibly proleptic, use of the aorist. 25

The actual historical reference need have nothing to do with AD 70; indeed it could reasonably be supposed to denote a number of different events in the years preceding the composition of 1 Thessalonians, as we shall see below. The severity of affliction experienced in Judaea under Caligula and Claudius may of course pale in light of the war of 66-73-but to say this presupposes the very hindsight that Professor Pearson would need to establish on other grounds. ${ }^{26}$ Some scholars, indeed, have even argued that the apocalyptic terminology and style of reasoning both in this passage and elsewhere in the letter should suggest that Paul's language does not require, and quite possibly does not even intend, any particular historical reference at all.27

In any case, Pearson's denial of Jewish persecution of Christians in Judaea between AD 44 and 66 has been variously called into question. ${ }^{28}$ Perhaps the most obvious exception is the martyrdom of James the Just in AD 62, whose symbolic significance Pearson's account seriously underrates. ${ }^{29}$ Various points of reference in the late 40s will be discussed below, as the most likely to be on Paul's mind. Even Paul himself had of course suffered repeated animosity from

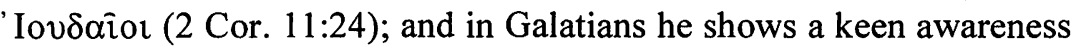
of ongoing Jewish persecution of Christians, evidently also in

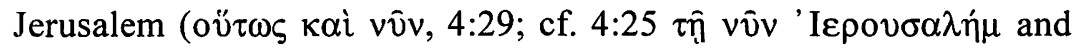

25 B.M. Fanning, Verbal Aspect in New Testament Greek (Oxford: OUP, 1990), 273-74 includes 1 Thes. 2:16 in his discussion of the 'proleptic' aorist, although he remains somewhat vague as to whether this passage should be included under the heading of 'occurrences which..., having started, have not been completed but which the circumstances show to be inevitable or for some other reason are viewed as certain'. Not all of Fanning's examples of the proleptic aorist seem equally compelling (he lists Mk. 11:24; 13:20; Lk. 1:51-54; Jn. 13:31; Rom. 8:30; 1 Thes. $2: 16$; Jude 14 ; Rev. 10:7; 11:2; 14:8; 15:1).

26 This is a point well made by Jewett, The Thessalonian Correspondence, 61, also quoted by Still, Conflict at Thessalonica, 35-36.

27 So e.g. Holtz, Der erste Brief an die Thessalonicher, 108-109; Wanamaker, The Epistles to the Thessalonians, 117.

28 Ironically, however, Still, Conflict at Thessalonica, 37-39 seriously weakens his own critique of Pearson by conceding the latter's claim and relating Paul's remark strictly to persecution of Jewish Christian 'Hellenists' in the early $30 \mathrm{~s}$.

29 Pearson, 'Interpolation', 86 n.45, 87; cf. e.g. Holtz, Der erste Brief an die Thessalonicher, 102 n.463. 
$6: 12^{30}$ ). Writing to Rome just six or seven years later, Paul still senses a continuing threat, not just to himself but to Christians generally, when he asks the church at Rome to pray that he may be delivered

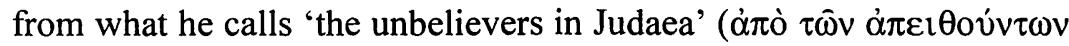

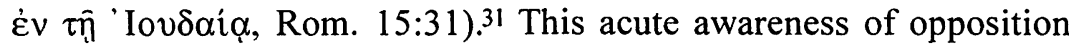
may well date back to the beginning of his gospel ministry 'from Jerusalem' (Rom. 15:19)-a phrase that in turn could bear directly on

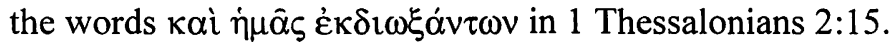

What is more, far from reflecting the Gentile anti-Judaism of later generations, as E.J. Richard has again asserted recently, ${ }^{32}$ most of the language used in verses 15-16 (with perhaps the partial exception of v. 15c) fits well within the milieu of several contemporary Palestinian Jewish sources. As various scholars have demonstrated, our passage can be appropriately interpreted in connection with the Deuteronomic and prophetic theme of the condemnation of Israel's unfaithfulness. This is also a well-rehearsed topos of contemporary inner-Jewish polemic that features prominently in a number of Second Temple texts, including not only Chronicles and the Psalms of Solomon, 33 but

30 The importance of Gal 6:12 is also pointed out e.g. by R. Jewett, 'Agitators and the Galatian Congregation', NTS 17 (1971), 198-212, at 206-208; Jewett, The Thessalonian Correspondence, 39 ; in this connection it may in turn shed light on $6: 16$.

31 So again Holtz, Der erste Brief an die Thessalonicher, $102 \mathrm{n.463}$; for $\dot{\alpha} \pi \varepsilon \mathrm{t} \theta \varepsilon \dot{\omega} \omega$ used of 'unbelievers', cf. Acts 14:2; 19:9; Rom. 10:21; 11:31; Heb. 11:31; Ignatius, Magn. 8.2; 1 Clem. 58.1. Paul's continued sensitivity to the threat of Jewish persecution makes unlikely the developmental argument that he changed his attitude after 'a great deal of water flowed under the bridge', between 1 Thes. 2 and Rom. 9-11 (so e.g. R. Penna, 'L'évolution de l'attitude de Paul envers les Juifs', in L'Apôtre Paul: Personnalité, Style, et Conception du Ministère, ed. A. Vanhoye (BETL 73; Leuven: University Press/Peeters, 1986), 390-421, at p. 419 and passim, who does not mention Rom. 15:31).

32 Richard, First and Second Thessalonians, 125-27.

33 Note 2 Ch. 36:16 ('They kept mocking the messengers of God, despising his words, and scoffing at his prophets, until the wrath of the Lord against his people became so great that there was no remedy') and cf. e.g. Ps. Sol. 8.4-22. Cf. further Vit. Proph. $1.1 ; 2.1 ; 3.2,16-19 ; 6.2 ; 7.1$ etc.; Asc. Isa. $2.1-11$ and passim; also Acts 7:52; Heb. 11:32-38. On 'filling up the measure of their sins' cf. Dn. 8:23; Wis. 19:4; Ps.-Philo, $L A B 26.13$ (and contrast 2 Mac. 6:14). This general point is well illustrated in I. Broer, "“Antisemitismus" und Judenpolemik im Neuen Testament: Ein Beitrag zum besseren Verständnis von 1 Thess 2,14-16', BN 20 (1983), 59-91, I. Broer, "Der ganze Zorn ist schon über sie gekommen": Bemerkungen zur Interpolationshypothese und zur Interpretation von 1 Thes 2,14-16', in The Thessalonian Correspondence, ed. R.F. Collins (BETL 87; Louvain: University Press, 1990), 137-59 and Légasse, 'Paul et les Juifs d'après 1 Thessaloniciens 2,13-16', 584; cf. also B.R. Gaventa, First and Second Thessalonians (Louisville: John Knox, 1998), 37 and earlier O. Michel, 'Fragen zu 1. Thessalonicher 2,14-16: Antijüdische Polemik bei Paulus', in Antijudaismus im Neuen Testament? 
also the Jesus tradition. ${ }^{34}$ Test. Levi 6.11 uses a virtually identical

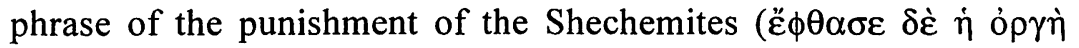

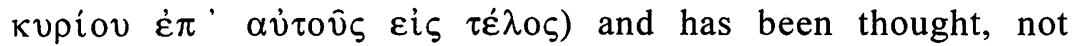
unreasonably, to indicate Paul's use of a familiar, quasi-proverbial turn of phrase. ${ }^{35}$

As H.W. Kuhn among others has shown, the language of Qumran is particularly worth comparing in this regard. The War Scroll and Community Rule, as attested in various text forms in Caves 1 and 4, are of course notorious for their lurid invocation of God's eschatological wrath upon their fellow Jews outside the sect (the sons of darkness, Belial and his lot, etc.). In fact, even the Hebrew phraseology employed shows intriguing parallels with Paul's

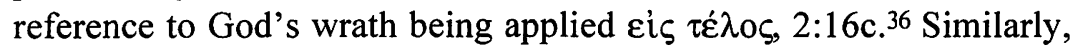
Qumran's pesher commentaries, like the book of Daniel before them (e.g. 8:19; 11:36 LXX), do not hesitate to see God's judgement upon their adversaries accomplished in what they regard as the fulfilment of prophecy in recent events. ${ }^{37}$

All this admittedly still leaves the four difficult assertions of verse 15 to be explained:

Exegetische und systematische Beiträge, ed. W.P. Eckert (Munich: Kaiser, 1967), 50-59.

34 See Mk. 12:1-12 par. Mt. 21:33-46, Lk. 20:9-19; Mt. 23:31-37 (cf. Lk. 11:4951). Wanamaker, The Epistles to the Thessalonians, 116 (who also cites J.B. Orchard, R. Schippers, W.D. Davies and D. Wenham) lists the parallels with Matthew 23: (1) the scribes and Pharisees are the sons of those who murdered the prophets (2:15a) and who 'fill up the measure' of their fathers' deeds $(2: 16 \mathrm{~b})$, thereby incurring God's just judgement $(2: 16 \mathrm{c})$. He rightly comments that the similarity between the two passages is the more significant in that both refer to Jewish opposition to the Christian mission.

35 See e.g. Holtz, Der erste Brief an die Thessalonicher, 109, who cites earlier scholars including Rigaux, Saint Paul: Les épitres aux Thessaloniciens, 112-13, 455-56, Milligan and Dibelius; cf. further E. W Stegemann, 'Zur antijüdischen Polemik in 1 Thess 2,14-16', Kirche und Israel 5 (1990), 54-64, 61; Légasse, 'Paul et les Juifs d'après 1 Thessaloniciens 2,13-16', 588; more cautiously E. Bammel, 'Judenverfolgung und Naherwartung: Zur Eschatologie des Ersten Thessalonicherbriefs', ZTK 56 (1959), 294-315, 309 n.l. Note, too, the logical sequence of the events on the aftermath of which Levi reflects in Test. Levi 6.8-11: divine sentence was pronounced on Shechem's sin, and then retribution from the Lord 'overtook them at last' as they were put to the sword.

36 Kuhn's examples include 1QM 3.9 (ער כלותם), 4.1-2 (לאין שהרית), 1QS 2.15-17 (לכלת עולמים), 4.13-14 (עד כלותם), 5.12-13 (לכלת עולם לאין שרית).

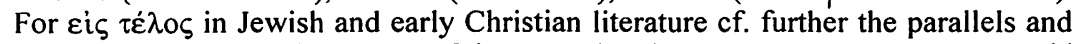
discussion in Bammel, 'Judenverfolgung und Naherwartung', 309 n.1; one could add other passages such as Test. Dan 6.5; 3 Bar. 13.2.

37 Note the pesherist's handling of the demise of the Wicked Priest or the punishment of unfaithful Israel by means of the Romans, e.g. in IQpHab 2.10-13; 9.9-12 and passim. 


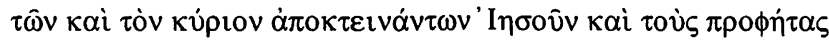

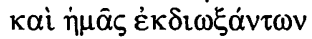

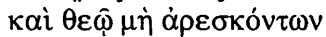

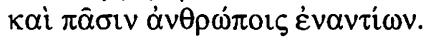

We should almost certainly remove the ('anti-Semitic'38) comma supplied by Nestle-Aland and most translations between verses $14 \mathrm{c}$ and 15: it is no more appropriate than to read in verse $14 \mathrm{a}-\mathrm{b}$ an emphatic indictment of all Gentiles at Thessalonica. Of course one should not deny the comprehensive, caricaturing nature of Paul's language. ${ }^{39}$ It reflects an understandable human expression of animus born out of adversity, a frame of mind in which all outsiders, whether hostile or merely apathetic, are readily lumped together as the enemy. Nevertheless, Paul's own writings elsewhere make it unlikely that he would hold all ethnic Jews accountable for the death of Jesus, or even to condemn them irredeemably in favour of Gentiles.

What is more, the use of the term' Iovoaior is notoriously complex and cannot $a$ priori be assumed to carry a comprehensive meaning: in Jewish texts, for example, it is at times specific to residents of Judaea and other active supporters of their national cause. ${ }^{40}$ Similarly, Luc

38 So F.D. Gilliard, 'The Problem of the Antisemitic Comma between 1 Thessalonians 2:14 and 15', NTS 35 (1989), 481-502; cf. e.g. J.A. Weatherly, 'The Authenticity of 1 Thessalonians 2:13-16: Additional Evidence', JSNT 42 (1991), 79-98, esp. 84-88, J.A. Weatherly, $1 \& 2$ Thessalonians (Joplin: College Press, 1996), 85-88. Prof. M. Wolter of Bonn, however, suggests to me the possibility that the comma may well be due to nothing more sinister than the Nestle-Aland editors' German syntactical sensibilities, which would be inclined to supply a comma even on a restrictive reading.

39 Note e.g. the caution of E. Verhoef, 'Die Bedeutung des Artikels tôn in 1 Thess 2,15', BN 80 (1995), 41-46; I. Broer, 'Antijudaismus im Neuen Testament? Versuch einer Annäherung anhand von zwei Texten (1 Thess 2,14-16 und Mt 27,24f)', in Salz der Erde, Licht der Welt: Exegetische Studien zum Matthäusevangelium: Festschrift für Anton Vögtle, eds. L. Oberlinner \& P. Fiedler (Stuttgart: Katholisches Bibelwerk, 1991), 321-55, esp. 328-29. Even in antiquity the text could be read more comprehensively in malam partem, as is seen in the fourth-century Ps.-Ignatius, Tars. 3.3, who speaks of Stephen being stoned $\pi \alpha \rho \grave{\alpha}$

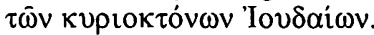

40 Contra P.W.L. Walker, Jesus and the Holy City: New Testament Perspectives on Jerusalem, (Grand Rapid: Eerdmans, 1996), 133, quoting N.T. Wright, The Climax of the Covenant: Christ and the Law in Pauline Theology, (Edinburgh: T. \& T. Clark, 1991), 156 n.61 ('Israel as a whole', 'Israel in principle'). For the wider issue of the meaning of 'Iovdaior see e.g. M.F. Lowe, 'Who Were the IOUDAIOI?' NovT 18 (1976), 101-30; M.F. Lowe, 'Ioudaios of the Apocrypha: A Fresh Approach to the Gospels of James, Pseudo-Thomas, Peter and Nicodemus', NovT 23 (1981), 56-90; and cf. the more nuanced treatments of S.J.D. Cohen, 'Ioudaios to genos and Related Expressions in Josephus', in Josephus and the History of the Greco-Roman Period: Essays in Memory of Morton Smith, eds. F. Parente \& J. Sievers (SPB 41 Leiden: Brill, 1994), 23-38; S.J.D. Cohen, 'Ioudaios: "Judaean" and "Jew" in Susanna, First Maccabees, and Second Maccabees', in 
Devillers has recently suggested that even the Fourth Gospel's notorious usage may need to be re-assessed in view of the curious detachment and remoteness that also characterises the reference to 'Iovdaîo in the letter of Soumaïos written in the Bar-Kokhba period and found at Wadi Murabba'at. ${ }^{41}$ The Qumran pesharim, too, do not shrink from polemical comments about Judaeans. ${ }^{42}$

Whether it functions in this more narrow sense here is not immediately apparent. Where necessary, Paul of course does not

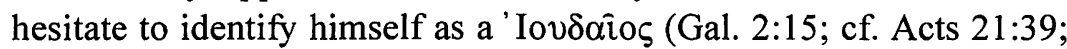
22:3); but his preferred self-designation is as an 'I $\sigma \rho \alpha \eta \lambda i \tau \eta \varsigma$ (Rom. 9:3-4; 11:1; 2 Cor. 11:22; cf. Acts 13:16) or a 'Eßpoîos (2 Cor. 11:22; Phil. 3:5). Since he may well be using language rooted in the Jesus tradition, as we saw above, the fact that he does not elsewhere attribute Jesus' death to 'the Jews' is hardly significant. ${ }^{43}$ Comparable statements are made about the inhabitants of Jerusalem in the early speeches of Acts $(2: 23,36 ; 3: 15 ; 4: 10 ; 7: 52)$.

Logically, as Rigaux, Holtz and others make clear, the point of the

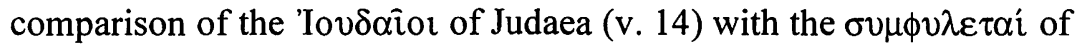
Thessalonica is in the first instance not primarily racial but social and ecclesial: in both locations, Christians are oppressed by their respective compatriots. ${ }^{44}$ It also reflects the privileged position of the original churches of Jerusalem and Judaea, whose suffering evidently remains in Paul's view paradigmatic for Christian experience elsewhere. ${ }^{45}$

Geschichte - Tradition - Reflexion, ed. H. Cancik et al., vol. 1 (Tübingen: Mohr Siebeck, 1996), 211-20 and G. Harvey, The True Israel: Uses of the Names Jew, Hebrew, and Israel in Ancient Jewish and Early Christian Literature (AGJU 35; Leiden: Brill, 1996).

41 See L. Devillers, 'La lettre de Soumaïos et les Ioudaioi johanniques.' $R B 105$ (1998), 556-81.

42 IQ15 1.5 interprets the 'shameless nation' of $\mathrm{Zp.} 2: 1$ as 'all the inhabitants of the land of Judah', while 4Q171 2.12-14 renders the arrogant wicked of Ps. 37:12 as 'all the violent of the Covenant who are in the house of Judah'. Elsewhere, as Harvey, The True Israel, 32-35 rightly points out, the Qumran writers tend to distinguish between the righteous and the wicked in Judah.

43 So also Holtz, Der erste Brief an die Thessalonicher, 104.

44 Rigaux, Saint Paul: Les épîtres aux Thessaloniciens, 443; Holtz, Der erste Brief an die Thessalonicher, 102.

45 Note in this regard the possibly parallel reference 'the churches of the saints' in 1 Cor. 14:33 (for 'the churches of God' cf. also 1 Cor. 11:16; 2 Thes. 1:4). It may be significant that one of the only two instances of pl. $\dot{\varepsilon} \kappa \kappa \lambda \eta \sigma^{\prime} \alpha \mathrm{l}$ in the LXX (Pss. $25(=26): 12 ; 67(=68): 27)$ occurs in a context clearly focused on Jerusalem, the Temple and God's ö́ror $(67(=68): 27,36)$. Note also the cognate phrase at Qumran (1QM 4.10), which corresponds remarkably closely to the more comprehensive singular usage attested in Acts 20:28; 1 Cor. 1:2; 10:32; 11:22; 
The historical reference of Paul's claim that the Jews 'drove us out' is ambiguous and difficult to locate with confidence. One recurrent line of argument has been to see here a direct and specific reference to the fierce Jewish opposition in Luke's account of the Pauline mission to Thessalonica and Beroea (Acts 17:5-9, 13).46 However, even if we leave aside the question of Luke's accurate knowledge of these events, ${ }^{47}$ there seems to be insufficient overlap between our v. 15 and Acts 17. Luke does not in fact describe an expulsion by the Jews of Thessalonica, and he makes the point that

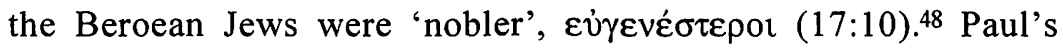
syntax, too, does not favour a direct connection with unpleasant memories in Thessalonica: grammatically as well as rhetorically, the two aorist participles of v. 15 are dependent on the compatriots of the

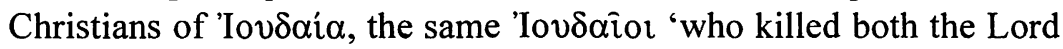
Jesus and the prophets and drove us out'. ${ }^{49}$ This would seem to suggest that Paul is referring to events in Jerusalem or Palestine of which we have only limited knowledge.

In both Galatians $(1: 19,22 ; 2: 2,4)$ and Romans (15:19 with 15:31), as we saw, the apostle hints at the personal danger he had long since faced in Jerusalem. It may be relevant that Luke links Barnabas' departure from Jerusalem and recruitment of Paul to the beginning of the Gentile mission in Antioch-a mission which in turn followed the persecution and dispersion of 'all except the apostles' after Stephen's martyrdom (11:19-20; cf. 8:1). Similarly, in the immediately following context (12:1-19) the persecution under Herod Agrippa

15:9; 2 Cor. 1:1; Gal. 1:13; 1 Tim. 3:5, 15. Paul's protestations of independence from Jerusalem in Galatians 1-2 (including, it seems, from 'the churches of Judaea who are in Christ Jesus', 1:22) serve a different rhetorical purpose, and need not detract from this perspective here.

46 Among recent interpreters, see e.g. K.P. Donfried, 'Paul and Judaism: 1 Thessalonians 2:13-16 as a test case', Interpretation 38 (1984), 242-53, esp. 247 48, C.G. Kruse, 'The Price Paid for a Ministry among Gentiles: Paul's Persecution at the Hands of the Jews', in Worship, Theology and Ministry in the Early Church, eds. M.J. Wilkins \& T. Paige (JSNTS 87; Sheffield: JSOT, 1992), 260-72, esp. 261-62 and Still, Conflict at Thessalonica, 201-203.

47 In Luke's favour, note that Paul in 1 Thes. 2:2 remembers that mission as having taken place $\dot{\varepsilon} v \pi 0 \lambda \lambda \hat{\varphi} \dot{\alpha} \gamma \hat{\omega} v \mathrm{v}$, and 2:3-12 presupposes that he is being maligned at Thessalonica.

48 Paul's reported experiences at Corinth (Acts 18:6, 12), which Still, Conflict at Thessalonica, 202 also adduces, have nothing to do with expulsion (note 18:18) and may in any case post-date the composition of 1 Thessalonians.

49 Had Paul really wanted to refer specifically to Macedonian events, against the grain of his deliberate comparison of Thessalonian vs. Judaean compatriots, one might have expected the clarifying addition of $\dot{\alpha} \dot{\phi} \dot{v} \mu \hat{\omega} v$ or the like. 
leads to the death of James and the exile of Peter. On this basis, it may be possible to read $\dot{\varepsilon} \kappa \delta \imath \omega \xi \dot{\alpha} \nu \tau \omega \nu \dot{\eta} \mu \hat{\alpha} \zeta$ here as encompassing two kinds of experience: first, the general developments of Christian persecution in Judaea, of which Paul himself was first a perpetrator and then, along with others, a victim; and secondly, by extension, the analogous events in a variety of other places, ranging from Damascus (2 Cor. 11:32-33) to Thessalonica itself (Acts 17:5-10, 13-14). ${ }^{50}$

The two last phrases of $v .15$ cited above are by far the most difficult, not least because they have no self-evident parallel in a firstcentury Jewish milieu, and do not obviously reflect Jewish or Christian traditional language. It is of course true that both the Dead Sea sectarians and even a writer like Josephus can accuse Jerusalemites of exhibiting qualities reminiscent of those alleged by Paul in v. 15.51 In their sweeping generality, however, there can be little doubt that Paul's assertions here are particularly marked by an element of passionate Middle Eastern hyperbole, ${ }^{52}$ as it moves from

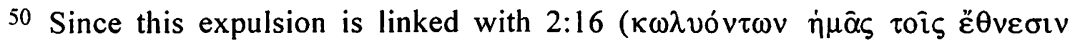
$\lambda \alpha \lambda \hat{\eta} \sigma \alpha \mathrm{l}$ iv $\alpha \sigma \omega \theta \hat{\omega} \sigma \mathrm{lv})$, it is again worth comparing 2 Cor. 11:24 along with several other passages in Acts that also speak of Paul's Gentile mission being 'hindered' by the Jews: e.g. $13: 34-50 ; 14: 2,19 ; 18: 12$. At the same time, the parallel with the activities of the 'false apostles' ( 2 Cor. 11:12ff.) and the 'false brethren' (2 Cor. 11:26; Gal. 2:4) underlines the fact that far from being representative of the Jerusalem church, these individuals are effectively in league with the persecutors.

Note also Penna, 'L'évolution de l'attitude de Paul envers les Juifs', 393, who suggests that 'Judaea' may well encompass Greater Palestine, and with it an allusion to Antioch and Paul's experiences at the hands of the 'circumcision party' (Gal. 2:12-13). Although this expansive interpretation of 'Judaea' seems to me illfounded in the present context, a 'Greater Israel' conception was certainly a feature of first-century Jewish belief (see M. Bockmuehl, Jewish Law in Gentile Churches: Halakhah and the Beginning of Christian Public Ethics (Edinburgh: T. \& T. Clark, 2000), 61-71, 75-79; cf. further M. Hengel, 'Ioudaia in der geographischen Liste Apg 2,9-11 und Syrien als "Grossjudäa", RHPR 80 (2000), 51-68).

51 See e.g. Josephus' condemnation of Jehoiakim as 'unjust and wicked by nature, and neither reverent to God nor kind to man' (Ant. 10.83). For the Dead Sea Scrolls see above, p. 10.

52 See especially Schlueter, Filling up the Measure, 111-85 and passim; L.T. Johnson, 'The New Testament's anti-Jewish Slander and the Conventions of Ancient Polemic', JBL 108 (1989), 419-41, esp. p. 419; cf. Wanamaker, The Epistles to the Thessalonians, 118-19 on vituperatio. The line between polemical hyperbole and prejudice may at times be very fine indeed, as R.A. Wortham, 'The Problem of Anti-Judaism in 1 Thess 2:14-16 and Related Pauline Texts', BTB 25 (1995), 37-44 suggests (although he fails to make sufficient allowance for the difference between external and internal polemic).

Middle Eastern politics recently provided an interesting illustration of the place of colourful polemics even among those whom one might have judged to be, broadly speaking, allies. Thus in August 1999 the Syrian defence minister Mustafa 
the aorist tense to the present, from specific allegations into the realm of caricature, and thus from the particular to the categorical. Daniel Marguerat has rightly documented the 'rhetoric of excess' that permeates chapter $2 ;{ }^{53}$ and the continuation of such rhetoric in 2:1416 confirms the impression of a consistent rhetorical Sitz im Leben.

As scholars have long observed, the language here does seem at face value to reflect some of the commonplaces of ancient anti-Jewish polemics, ${ }^{54}$ and regardless of Paul's own intention we must accept that his Gentile readership could very well have understood his remarks in that sense, in malam partem. Even so, it is important to

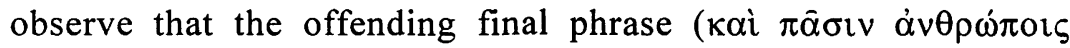
$\dot{\varepsilon} v \alpha v \tau i \omega v)$ is in particularly close syntactical correlation with the

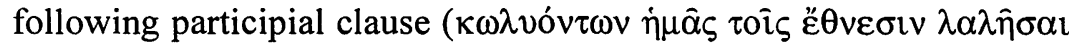
iv $\alpha \sigma \omega \theta \omega \bar{\sigma}(v)$. Significantly, the two are linked without conjunction or article; indeed it seems worth removing Nestle-Aland's comma here, too-or placing it after $\dot{\alpha} \rho \varepsilon \sigma \kappa o ́ v \tau \omega v$, to show that grammatically the last three words of v. 15 modify the first clause of v. 16. The function of the entire clause introduced by $\kappa \alpha i$, then, is almost epexegetical: in other words, the persecuting Jews' affront to God and opposition to all humankind comes to expression precisely in their hindrance of the apostolic mission for the salvation of the Gentiles. 55 This categorical accusation of 'the Jews', then, is characterised theologically and soteriologically, and not in the sweeping sociocultural sense in which Tacitus adopted it two generations later under

Tlass referred to fellow Arab statesman Yasser Arafat as 'the son of 60,000 whores' for making too many concessions to Israel, especially on Jerusalem. 'General Tlass, whose multitalented achievements include a treatise on garlic's place in Islamic life, later denied that he was attacking Mr Arafat personally, only his policy' (The Economist, 7.8.1999, p. 4).

53 D. Marguerat, 'L'apôtre, père et mère de la communauté (1 Th $2 / 1-12)$ ', ETR 75 (2000), 373-90.

54 In addition to Tacitus' notorious charge (adversus omnes alios hostile odium: Hist. 5.5), Josephus discusses similar accusations in Ap. 1.310; 2.125, 148; cf. LXX Esth $3: 13^{\mathrm{e}}$. Parallels have been well documented in the commentaries: see e.g. Holtz, Der erste Brief an die Thessalonicher, 105, citing M. Dibelius, An die Thessalonicher I, II, An die Philipper (HNT 11; 3rd edn.; Tübingen: Mohr Siebeck, 1937), 34-36; cf. also the evidence collected e.g. in M. Whittaker, Jews and Christians: Graeco-Roman views, (Cambridge: CUP, 1984), 20-23, 34, 43-45 and passim; P. Schäfer, Judeophobia: Attitudes toward the Jews in the Ancient World (Cambridge: HUP, 1997), 15-118.

55 So e.g. E. Best, A commentary on the first and second Epistles to the Thessalonians (BNTC; London: A. \& C. Black, 1972), 117; Holtz, Der erste Brief an die Thessalonicher, 106; Légasse, 'Paul et les Juifs d'après 1 Thessaloniciens 2,13-16', 582; Penna, 'L'évolution de l'attitude de Paul envers les Juifs', 395, 397; Wanamaker, The Epistles to the Thessalonians, 115. 
Hadrian (see n. 54 above). Thus, even if Paul were consciously echoing contemporary anti-Jewish polemic, here these words have certainly been given a highly particular application, estranged from its usual pagan setting.

There is doubtless a good deal more to be said; in particular, we could comment further on Pearson's adoption of doubtful formcritical considerations ${ }^{56}$ and on his arguments from Paul's use of mimésis, as cited earlier. ${ }^{57}$ Nevertheless, all that needs to be established for our purposes is the reasonable likelihood that our text was an integral part of Paul's first letter to Thessalonica-a position that appears to be regaining ground in recent scholarly opinion. ${ }^{58}$ Chapter 2 presents Paul's rhetorically charged application of the gospel message and ministry to the Thessalonian church. In that immediate context, our text offers a concrete re-application of the repeated motif of the imitation of Christ and the apostles. Recurring as it does both before and after our passage (1:5-6; 4:1; cf. 2:1-12), this motif constitutes an additional argument for textual integrity. For the

56 Pearson, 'Interpolation', 88-91. Our earlier point about the largely 'experimental' nature of Paul's early letters requires the usual rhetorical and formcritical arguments for an interpolation to be taken with a grain of salt. Note, conversely, the balancing (but in my view equally dubious) argument of Wick, 'Ist I Thess 2,13-16 antijüdisch', 21-23 for a deliberate structural parallel of motifs between the pagan anti-Judaism of 2:14-16 and the Jewish anti-paganism of 4:2-8.

57 Pearson, 'Interpolation', 87-88. He claims that Paul does not elsewhere commend the mimésis of anyone other than himself. But 1:5-6 and 4:1 show clearly that Paul is consistent with his own argument here. Imitation of Paul is in fact implicit in 2:14, consistent with other aspects of 2:1-12. Compare further the commendation of Timothy in Phil. 2:19-30 (esp. 29-30).

58 Recent advocates of authenticity include Collins, Studies on the First Letter to the Thessalonians, Jewett, The Thessalonian Correspondence, 36-42, Légasse, 'Paul et les Juifs d'après 1 Thessaloniciens 2,13-16' and S. Légasse, Les Épitres de Paul aux Thessaloniciens (LD Commentaires 7; Paris: Cerf, 1999), 141-65, Schlueter, Filling up the Measure, Still, Conflict at Thessalonica and Wanamaker, The Epistles to the Thessalonians, 29-33; see further the list in Still, Conflict at Thessalonica, 25-26 n.4.

Note R.F. Collins's prudent conclusions on the matter (Collins, Studies on the First Letter to the Thessalonians, 124-25), which apply in equal measure to the interpolation and the compilation theories: 'It is, in fact, the lack of integrity of the letter which must be proved rather than the inverse. The existence of 1 Thes as it now stands is a datum for our reflection. That 1 Thes has existed as a single text is evidenced by the unanimous witness of the manuscript tradition. The extant external evidence unquestionably supports the integrity of our letter. The integrity of the letter, therefore, should remain the basic assumption and working hypothesis for the explication of the text...' For discussion of recent scholarship on this text see further Broer, 'Bemerkungen zur Interpolationshypothese'; Collins, Studies on the First Letter to the Thessalonians, 97-114; Schlueter, Filling up the Measure, 164; Riesner, Paul's Early Period, 404-11; Still, Conflict at Thessalonica, 24-45. 
Thessalonian Christians, the intensity of their compatriots' opposition should be seen as analogous to the severity of afflictions endured by Jerusalem Christians. Such oppression ought not to come as a surprise, since Paul himself had frequently reminded the church that tribulations of this nature would necessarily come (3:4), as judgement on God's enemies is about to begin (cf. 5:1-11).

\section{c) Date}

Closely related to the previous issue, and of equal importance to the question at hand, is a brief account of the letter's date. By widespread scholarly consensus, 1 Thessalonians is one of the earliest extant letters of Paul, quite possibly the first.

Pauline chronology remains notoriously complex and contested, as any comparison of recent surveys will show. Operating on the simplest of correlations between Acts and Paul's letters, however, one arrives at broad scholarly agreement on the fact that Paul proceeded from Thessalonica via Athens to Corinth. It is there that Paul eventually appeared before the proconsul Gallio, and where the vast majority of exegetes assumes that 1 Thessalonians was composed perhaps shortly after Paul's arrival. ${ }^{59}$ Paul's co-signatories in the letter are listed in 2 Corinthians $1: 19$ as joint founders of the Corinthian church. Yet the lack of greetings from the church at Corinth suggests to some scholars a date of 1 Thessalonians soon after Paul's arrival, before any significant numbers of converts were made. 60

This also seems to be implied by Paul's repeated rhetorical assumption of relatively fresh reminiscence in the letter itself (e.g. 1 Thes. $1: 5 ; 2: 1,5,9,10)$, along with the suggestion that his absence had only been for a short time (2:17). Timothy had set out for a visit while Paul was still at Athens; and upon his very recent return with good news Paul immediately puts pen to paper, perhaps in part to answer Thessalonian problems or queries of which Timothy has also reported.

Everyone agrees that Paul's appearance before Seneca's brother Gallio, the proconsul at Corinth, is a pivotal date for any Pauline chronology. However, a number of incompatible dating schemes

59 The most widely noted exception is perhaps G. Lüdemann, Paul, Apostle to the Gentiles: Studies in Chronology, trans. F.S. Jones (London: SCM, 1984), although he has not been widely followed.

60 So e.g. Holtz, Der erste Brief an die Thessalonicher, 11, also cited with approval by Riesner, Paul's Early Period, 364-65. 
continue to be asserted, ${ }^{61}$ some of them with dizzying claims to certainty. ${ }^{62}$ Here is not the place for a definitive resolution of this matter. Nevertheless, Gallio's tenure is almost universally associated with the year 51 . On this basis, then, we may most plausibly date 1 Thessalonians, including 2:14-16, in AD 50.

\section{1 Thes. 2:14-16 and Jerusalem in AD 48-49}

Our desk having been somewhat incompletely cleared of introductory matters, we may turn in the remainder of this paper to the historical problem at the centre of our inquiry. Assuming the authenticity of $2: 14-16$, what are the historical events in Judaea that gave rise to Paul's claims of persecution followed by the inauguration of God's definitive judgement?

This question is by no means as straightforward and familiar as one might assume in the face of an exhaustively analysed passage such as ours. This is so for two main reasons. First, it has to most scholars seemed difficult to identify particular historical circumstances in the first two decades of Palestinian Christianity that would make even an approximate fit with Paul's language. No consensus has been reached about where to locate either a murderous persecution analogous to that of Jesus and the prophets $(2: 15)$ or indeed the subsequent, and seemingly consequent, punishment of sufficiently cataclysmic

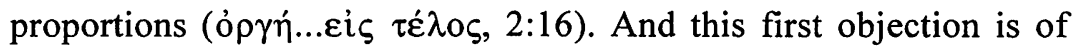
course entirely reasonable: although it is an argument from the supposed silence of the sources, in the face of Paul's far-reaching assertion such silence, if confirmed, would indeed be eloquent.

A second difficulty derives from the considerable body of exegetical opinion that appears to have made a virtue of necessity in regarding the historical question as intrinsically misguided and unanswerable. Especially v. 16, it is said, need not envisage any identifiable event. Among the reasons given are that Paul's language is apocalyptic in nature and therefore by definition 'expressive' and poetic rather than 'referential', ${ }^{63}$ and wholly independent of any

61 The most comprehensive recent survey may be Riesner, Paul's Early Period, 328, 318-26; cf. also Murphy-O'Connor, Paul: A Critical Life, 1-31.

62 See e.g. Murphy-O'Connor, Paul: A Critical Life, 28, 'These dates, it should be remembered, are the rock-bottom minimum.'

63 So e.g. Wanamaker, The Epistles to the Thessalonians, 117, citing J.J. Collins, The Apocalyptic Imagination: An Introduction to the Jewish Matrix of Christianity, (New York: Crossroad, 1984). Cf. C. Masson, Les Deux Epitres de saint Paul aux 
historical correlations that may or may not exist. ${ }^{64}$ (But this is surely an extraordinary claim in view of the contrary evidence in a host of apocalyptic texts from Daniel to Revelation and 4 Ezra...) For others, conversely, the volatile and fanciful apocalyptic mind is so given to jump to dramatic conclusions that even perfectly insignificant events would quite suffice to convince it of the arrival of the end-time woes. ${ }^{65}$ Yet another expedient to keep Paul's reference unspecific is to treat the aorist $\ddot{\phi} \phi \theta \alpha \sigma \varepsilon v$ either as exclusively prophetic (and future) in meaning 66 or in the sense of repeated, typical action in the past and thus in the sense that Jewish obstinacy in the past 'has always resulted in divine punishment' and will inevitably do so now. ${ }^{67}$

Some of these clever insights may well have great explanatory force in the grammatical or hermeneutical realm; I do not know. For the limited purposes of the present discussion, however, they seem in important respects to be putting the cart before the horse. On taking the plain sense of the passage, one is led to believe, first, that both Paul and the Judaean Christians have been subject to sustained Jewish persecution. Although expressed in specific (possibly violent) actions, ${ }^{6}$ that persecution has been of an extended duration rather than confined to one particular occasion in the increasingly distant past. ${ }^{69}$ And secondly, it seems that this Jewish hostility has now been followed, perhaps by implication relatively recently, by concrete circumstances that suggest to Paul the inauguration of definitive divine judgement.

Thessaloniciens (CNT 11a; Paris: Delachaux \& Niestlé, 1957), 35, 'Dans un texte si nettement eschatologique, ce serait une erreur de reconnaître la manifestation de la colère dans un événement historique quelconque.'

64 Cf. Holtz, Der erste Brief an die Thessalonicher, 108-109.

65 So e.g. J.C. Hurd, 'Paul ahead of his Time: 1 Thess 2:13-16', in Anti-Judaism in Early Christianity, ed. E.P. Sanders, vol. 1 (Waterloo: Wilfred Laurier University Press, 1986), 21-36, 45; Still, Conflict at Thessalonica, 36; cf. Best, Commentary, 120.

66 So e.g. recently Weatherly, $1 \& 2$ Thessalonians, 92; cf. Best, Commentary, 120; Rigaux, Saint Paul: Les épîtres aux Thessaloniciens, 454-55; Masson, Les Deux Epitres de saint Paul aux Thessaloniciens, 35, following earlier suggestions by von Dobschütz, Bultmann and others.

67 Stegemann, 'Zur antijüdischen Polemik in 1 Thess 2,14-16', 60-61 and n. 44; the examples he cites for such a use of the aorist (2 Cor. 11:25; Mk. 12:41; Lk. 13:34; Acts 11:26) are hardly illuminating for the case at hand. Cf. already Bammel, 'Judenverfolgung und Naherwartung', 308 n.4 in critique of a similar position.

68 Note the actions associated with the aorist participles $\dot{\alpha} \pi \circ \kappa \tau \varepsilon \iota v \alpha \dot{\alpha} \tau \omega \nu$ and $\dot{\varepsilon} \kappa \delta \imath \omega \xi \dot{\alpha} v \tau \omega v$.

69 Note the present participles of vv. $15 b-16$ and the use of $\pi \alpha$ vio $\tau \varepsilon$, all of which grammatically qualify the Jewish persecution of v. 14 . 
The study of history may of course render impossible or at least unlikely the twin scenarios evoked by this relatively straightforward reading; and so it has seemed to many. In that case, we would indeed need to cast about for alternative readings. On simple exegetical grounds, however, it arguably remains the case that if a satisfactory pair of historical points of reference can be identified, this ought to take precedence over typological, symbolic or other non-literal interpretations. ${ }^{70}$ The least we must say is that both the Judaean persecution of v. 14 and the initiation of divine wrath in v. 16 are described as fact. ${ }^{71}$ It is in this connection that I wish to put forward a proposal which, although not wholly unprecedented, may possibly offer some fresh bait to a discussion that has for a number of years confined itself to a habitual range of intractably disparate views.

\section{Jewish Persecution of the Judaean Churches}

Regardless of their stance on the authenticity of our text, scholars agree that the Acts account of the first two Christian decades envisages at least two periods of notable violence against Christians in Judaea.

Developments in the mid-30s. The first of these is the execution of Stephen and its aftermath. Luke casts Stephen's martyrdom in deliberate analogy to that of Jesus, and even links the charges against him to Jesus' pronouncements against the Temple.72 In view of this it

70 Cf. B.W. Bacon, 'Wrath "Unto the Uttermost", The Expositor 8.24 (1922), 356-76, who declares himself 'unable to regard the figurative sense [sc. of $\ddot{\varepsilon} \phi \theta \alpha \sigma \varepsilon v]$ as so "natural" as to warrant the setting aside of the self-evident principle that the usual and literal sense must take precedence wherever possible' (p. 362).

71 The aorist $\check{\varepsilon} \phi \theta \alpha \sigma \varepsilon v$ here demands reference to an event that has at least been initiated, if not completed. While it may of course prefigure ultimate judgement, it cannot plausibly be reduced to an exclusively prophetic or general sense. So rightly Pearson, 'Interpolation', 81-83; see also p. 8 and n. 25 above. Cf. further G.E. Okeke, ' 1 Thessalonians 2:13-16: The Fate of the Unbelieving Jews', NTS 27 (1980), 127-36, esp. 130-31; Holtz, Der erste Brief an die Thessalonicher, 108 and Légasse, 'Paul et les Juifs d'après 1 Thessaloniciens 2,13-16', 588-89 ('cet aoriste énonce un fait révolu'), although they contend that the eschatological context means that no particular event need be in view. The likelihood of a more particular reference here in no way detracts from Penna's important observation of a more general analogy between Paul's declarations of God's wrath upon unbelieving Jews in 1 Thes. 2:16 and Rom. 9:22 (see Penna, 'L'évolution de l'attitude de Paul envers les Juifs', 396-7).

72 On the latter logia see most recently the nuanced work of K. Paesler, Das Tempelwort Jesu: Die Traditionen von Tempelzerstörung und Tempelerneuerung im Neuen Testament (FRLANT 184; Göttingen: Vandenhoeck \& Ruprecht, 1997); $\mathrm{cf}$. further J. Ådna, Jesu Stellung zum Tempel: Die Tempelaktion und das Tempelwort als Ausdruck seiner messianischen Sendung (WUNT 2:119; 
seems reasonable to suppose, as the Pseudo-Clementines do, that this first violent episode may have taken place in the early to mid-30s, while Caiaphas was still in office. ${ }^{73}$ It will then have been part of a continuing purge of Jesus' followers in which Saul of Tarsus played for a time a prominent role.

Alternatively, it is possible to envisage this (or a similar?) High Priestly action as taking place during the procuratorial interregnum after Pilate's deposition in AD $36 .^{74}$ Such a pattern, at any rate, would be comparable to the executions of James the son of Zebedee after Caligula's demise in 41 (see below), and of James the Just under Annas the son of Annas after the death of Festus in 62 (Jos. Ant. 20.200-203).

Herod Agrippa I and $A D$ 41/42. A similar hiatus of direct Roman rule arose when the Emperor Claudius, newly installed on 24th January of the year 41, rewarded Herod Agrippa's loyalty by rescinding Judaea's provincial status and instead adding it and Samaria to the territory under Agrippa's control. In his early years Claudius seems to have favoured the Jews, publishing two edicts guaranteeing their religious freedom while exhorting them in turn to manifest tolerance, apparently in the aftermath of the Alexandrian riots under Caligula. 75

Like Philo and Petronius, among others, Agrippa had worked hard to dissuade Caligula from his disastrous attempt to erect his statue in the Temple. Upon coming to power in Judaea, he took pains to show himself an observant Jew, thereby attempting to calm the explosive religious and political atmosphere in the aftermath of Caligula's very nearly successful sacrilege. In Josephus and rabbinic literature alike, Agrippa appears as a faithful adherent of the Temple who brought daily offerings, played a prominent role in the Festivals, and paid for the sacrifices of large numbers of Nazirites. ${ }^{76} \mathrm{He}$ was clearly a

Tübingen: Mohr Siebeck, 2000), B. Chilton \& C.A. Evans, Jesus in Context: Temple, Purity, and Restoration, (AGJU 39; Leiden: Brill, 1997).

73 See Ps.-Clem. Rec. 1.71.

74 See also the discussion in Riesner, Paul's Early Period, 59-63.

75 Josephus, Ant. 19.279-91. On the authenticity of these edicts see e.g. Riesner, Paul's Early Period, 98-99; J.M.G. Barclay, Jews in the Mediterranean Diaspora: From Alexander to Trajan (323 BCE-117 CE) (Edinburgh: T\&T Clark, 1996), 5658. Cf. also lines 88-100 of $C P J 1.153$, a copy of the subsequent letter of Claudius to the Alexandrians in $\mathrm{AD} 41$.

76 See e.g. Josephus Ant. 19.294, 321; m. Bik. 3.4; m. Sotah. 7.8. Note, however, D.R. Schwartz's telling point that, unlike the rabbis, Josephus and similarly Philo seem 'to have had no sources antagonistic to Agrippa' (Agrippa I: The Last King of Judaea (TSAJ 23; Tübingen: Mohr Siebeck, 1990), 157). 
supporter of the national cause in other ways, too, including his initiative to construct a fortified third (northern) wall of Jerusalem. Had this project been completed, Josephus claims it would have rendered Jerusalem impregnable to the Roman army. ${ }^{77}$

Perhaps precisely because of these policies favouring nationalist and especially Sadducean interests, ${ }^{78}$ this popular and supposedly mild-mannered king also features in Acts in the seemingly unlikely role of persecutor of the Jerusalem church. His deliberate policies of 'pleasing the Jews' (Acts 12:3) included inter alia the small-scale, ${ }^{79}$ but symbolically significant elimination of leading disciples of Jesus of Nazareth - a man who in recent memory had also (like Caligula) been thought to pose a serious threat to the Temple. Thus, Agrippa executed James the son of Zebedee 80 and arrested Simon Peter-someone who may have been publicly tainted not only by his association with Jesus, but by controversial links with Gentiles in his own right. After his miraculous escape, Peter fled Jerusalem for a

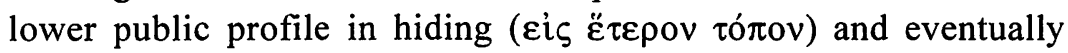
relocated to Antioch. James's execution, and Peter's arrest, may well have taken place in late March or early April $41 .{ }^{81}$

Persecution in 48/49? The problem is that these events may thus transpire a full nine years before Paul wrote 1 Thessalonians 2:14. In our passage, however, the Apostle to the Gentiles shows himself remarkably exercised by the continuing fate of the Judaean churches, and unusually willing to read some apparently recent developments as heralding sovereign divine judgement.

It would seem most reasonable to begin from the assumption that memories of both experiences are fresh in his mind. With regard to 'divine wrath', there has in fact been no shortage of proposals among the calamities suffered by Jews during the turbulent years $48-49$, as

77 Ant. 20.218.

78 Cf. Schwartz, Agrippa I: The Last King of Judaea, 130 and passim.

79 So also Ibid., 122-23.

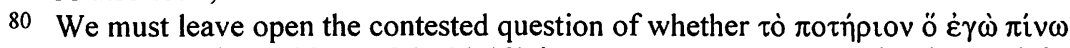
$\pi i \varepsilon \sigma \theta \varepsilon, \kappa \tau \lambda$. (Mk. 10:39 par. Mt. 20:23) is a vaticinium ex eventu, but it certainly confirms that Paul is following early tradition in linking the fate of Jesus with that of the Judaean churches.

81 Cf. Riesner, Paul's Early Period, 118-21, who considers it likely that Agrippa took action against the church as part of his pro-Temple policy from the very start, and also relates Peter's likely departure in AD 41-42 to an apocryphal tradition, widely attested in the Kerygma Petri and elsewhere, that Peter left Jerusalem 12 years after the crucifixion (so also Bacon, "Wrath "Unto the Uttermost", 372-75). Passover 42 remains a possible alternative, however, especially if (as e.g. Schwartz, Agrippa I: The Last King of Judaea, 164 argues) Agrippa did not return to Jerusalem until after Pentecost 41. 
we shall see in a moment. What has proved rather more difficult, however, is the positive identification of any recent harassment of Jewish Christians. Without such data, it is more difficult to be confident (1) that palpable hostility to the Judaean churches did indeed continue, at least sporadically, throughout the $40 \mathrm{~s}$, and (2) that whatever Paul may have in mind in v. 16c could reasonably have appeared to Christians as at least inaugurating divine retribution on the heels of such persecution.

The New Testament appears silent on this question. Aside from a few scattered allusions to the suffering of the Judaean churches over the decade or so of Paul's extant correspondence, scholars have uncovered virtually no specific evidence to confirm a persecution of Christians in Judaea in the late $40 \mathrm{~s} .{ }^{82}$ Acts, for example, shifts the focus of its narrative decidedly away from Jerusalem between the note about Peter's departure (ch. 12) and the much-queried account of the apostolic council (ch. 15) - and thus including the crucial period here in view. Of course it may be that the Judaean prophets who arrive in Antioch (11:27) or Caesarea (21:10) have left Jerusalem under acute duress; but Luke offers little by way of confirmation.

There is, however, one relatively obscure ancient source that in my view deserves further consideration-not so much in its own right, but as offering corroboration of certain aspects of the evidence in 1 Thessalonians and Galatians (and later on in Romans). The sixthcentury chronicler Malalas of Antioch makes the remarkably precise claim that a further significant Jewish persecution of the apostles and their followers did in fact take place in AD 48/49 ('in the eighth year of Claudius'). 83 Malalas of course is by no means wholly impartial and reliable in his account of this material, and should only be used to illustrate and annotate, rather than to establish, our knowledge of the period. Nevertheless, while the tenuous nature of this evidence makes

82 True, if the 'prophets' in view were to be the early Christian prophets of Judaea (cf. Acts $11: 27 ; 15: 32 ; 21: 10$ ), as some have argued on the basis of their being listed after Jesus, then Paul's assertions about them would certainly be in keeping with the dominical expectation voiced in the ' $Q$ ' logion Lk. 11:49 par.: 'I will send them prophets and apostles, some of whom they will kill and persecute

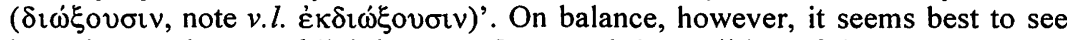
here the usual general link between Jesus and the tradition of the persecution of the prophets, which may include Jewish as well as Christian ones. Note that

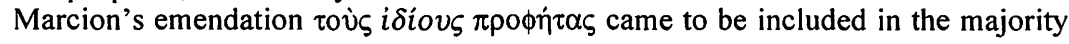
text.

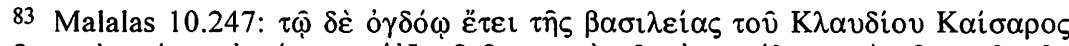

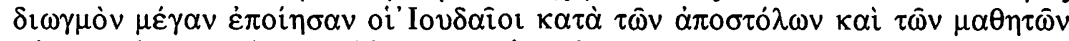

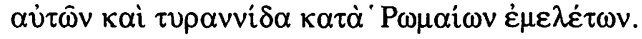


confirmation impossible, there is no obvious reason why such a specific reference to a persecution in AD 48/49 should have been invented. Renewed persecution of this kind might indeed help to substantiate the impression of 'fresh memories' in 1 Thessalonians $2: 14-16$. And it would fit the context of the violent upheavals under Ventidius Cumanus, as we shall see below.

Beyond that, however, such a backdrop may well help to clarify and lend more vivid colour to several matters in Paul's letter to the Galatians. Thus, we may see here (1) some of the reasons behind the apparent secrecy of the Jerusalem agreement (Gal. 2:9), for which Peter had perhaps returned at some danger to himself after previously fleeing the city (only the 'pillars' seem to have been present; cf. Gal. $2: 1,2: 9$; Acts $12: 17 ; 15: 7)$. (2) Similarly, renewed persecution may explain the reasons for Peter's post-conciliar move to the politically safer jurisdiction of Antioch, having initially fled Agrippa's Jerusalem for the relative shelter of 'another place' (Acts 12:17; Gal. 2:11). (3) In addition, such a context could supply some of the contributing factors behind James the Just's intervention in Antioch (Gal. 2:12). ${ }^{84}$ (4) Finally, it would clarify the interpretation of at least two allusions to Jewish persecution of Jewish Christians $(4: 26,29 ; 6: 12$; cf. 6:16?). For 1 Thessalonians, it may even be possible to speculate that Paul, chastened after reflection on his defeat at Antioch, has come to take more seriously the news about the sufferings of the Judaean churches that led to the appeal from James.

The upshot of such a link between Galatians and 1 Thessalonians would be to shed light on the setting of both - and perhaps in the process to invite the reconsideration of an earlier date of Galatians, after the apostolic council but perhaps shortly before or shortly after 1 Thessalonians. ${ }^{85}$

84 On this question see my fuller remarks in Bockmuehl, Jewish Law in Gentile Churches, 61-79.

85 I see no cogent objections against such a date of Galatians in the near aftermath of the Antioch incident itself (so e.g. J.D.G. Dunn, $A$ Commentary on the Epistle to the Galatians (BNTC; London: A. \& C. Black, 1993), 19; cf. C. Breytenbach, Paulus und Barnabas in der Provinz Galatien: Studien zu Apostelgeschichte 13f.;16,6;18,23 und den Adressaten des Galaterbriefes (AGJU 38; Leiden: Brill, 1996), 172-73). Aside from his still rather acute exasperation about the events at Antioch, Paul seems here to look back on the foundation of the (South) Galatian churches in AD 47-48 as relatively recent: he declares himself astonished that the Galatians have 'so quickly' deserted the gospel (1:6) at a time when they should still have in mind the visual image of the apostle's demonstration of Christ $(3: 1)$. The reference to the beginning of his mission to Galatia at 4:13 ( $\tau$ ò $\pi \rho o ́ \tau \varepsilon \rho o v$ ) cannot be taken as evidence that Paul had visited more than once. 


\section{AD 44-49 as the Beginning of God's Final Wrath?}

If there was indeed a further persecution of Christians in Judaea in the year 48/49, it becomes rather clearer why Paul's reflection on the subsequent 12-18 months might cause him to conclude that divine retribution was now palpably beginning to overtake the persecutors. This is what the aorist $\ddot{\varepsilon} \phi \theta \alpha \sigma \varepsilon v$ arguably presupposes, even if it is clear from 1:10 and 5:9 that such judgement must still be read in relation to the 'ó $\rho \gamma \eta$ to come'.

\section{a) The Events of 48-49}

The year 48-49 was certainly an annus horribilis in Jewish history, as has long been acknowledged in this connection. ${ }^{86}$ First, this year saw the beginning of Ventidius Cumanus's disastrous tenure as procurator of Judaea (48-52), amply documented in Josephus. ${ }^{87}$ In particular, during the second half of the Passover week in 49, the incensed crowd's reaction to a single soldier's provocative gesture led Ventidius Cumanus to a catastrophic misjudgement. Reinforcing the usual token presence of 128 soldiers guarding the Temple porticoes, he authorised the massive deployment of fully armed soldiers onto the hopelessly overcrowded Temple mount. Josephus claims that several tens of thousands perished. ${ }^{88}$ Not surprisingly, he adds,

So there was mourning instead of feasting; and all, utterly oblivious of prayers and sacrifices, turned to lamentation and weeping. Such were the calamities produced by the indecent behaviour of a single soldier. ${ }^{89}$

This bloodbath in Jerusalem was followed by various violent reprisals at Beth-Horon and Jenin in the year 49, after which Ummidius Quadratus, the governor of Syria, proceeded to crucify the prisoners Cumanus had taken and to behead eighteen others. He eventually sent

86 See the seminal treatments by Bacon, "Wrath "Unto the Uttermost"' and S.E Johnson, 'Notes and Comments (I Thess 2:16)', ATR 23 (1941), 173-76, preceded in significant respects by W. Grimm, 'Die Echtheit der Briefe an die Thessalonicher, gegen D. Baur's Angriff vertheidigt', TSK 23 (1850), 753-816, esp. $773-75$ (N.B. before him, Ventidius Cumanus had already been envisaged by J.A. Bengel, Gnomon Novi Testamenti, 3rd edn. (London: Nutt/Williams \& Norgate, 1855), 324, first published in 1742).

87 Ant. 20.103-36; War 2.223-45. Note also the somewhat garbled account in Tacitus, Annals 12.54 (on which see e.g. E. Schürer, A History of the Jewish People in the Age of Jesus Christ, ed. G. Vermes et al., Rev. edn., 3 (4) vols. (Edinburgh: T. \& T. Clark, 1973-86), 1.459-60 n.15).

88 Either 20,000 (Ant. 20.112) or more than 30,000 (War 2.227) died in the resulting stampede.

89 Ant. 20.112; cf. War 2.227. 
the High Priest Ananias and his colleagues to Rome in chains to appear before Claudius. ${ }^{90}$

If the Jewish Christian persecution of 48 did not in fact precede these events, the turbulent and at times near-anarchic atmosphere during the first year of Ventidius Cumanus's appointment ${ }^{91}$ would in any case have given plenty of scope for the $\delta i \omega \gamma \mu$ ó envisaged by Malalas. What is more, his brief note may rightly imply that such persecution could have been the by-product of a wider nationalist insurrection (if that is how we should take the curious phrase $\alpha \alpha i$

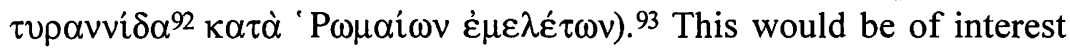
especially if (as has often been suggested) part of the reason for renewed pressure on the Judaean Christians ahead of the Antioch incident was their insufficient support for the nationalist cause and perceived association with Gentiles. (This same issue may also shed light on Peter's move to Antioch, as we noted earlier.) Josephus in any case implies that when Felix took up the office of procurator $c$. AD 52 , he found the country 'infested with bands of brigands and impostors who deceived the mob' (Ant. 20.160).

\section{b) Other Developments in 44-49}

If one correlates these episodes of the year 48-49 with the general political climate since the return of the Roman procurators in $A D 44$, it is not difficult to see why the years since the death of Agrippa, the last Jewish king of Judaea, ${ }^{94}$ might have been widely regarded as bringing a decisive downturn for Jewish life in Jerusalem and Judaea. As Schürer/Vermes puts it, 'It might be thought, from the record of the Roman procurators to whom, from now on, public affairs in Palestine

90 On the latter incident see War 2.236-45; Ant.20.118.

91 Note e.g. Ant. 20.120-24; 2.233-35, 39.

92 While in classical Greek this term usually means political sovereignty or power, later sources not infrequently employ it in the sense of illegitimate usurpation of power, i.e. of insurrection: see e.g. $P G L$ s.v. (p. 1421).

93 Scholars rightly discount Malalas' claim that it was this uprising which caused

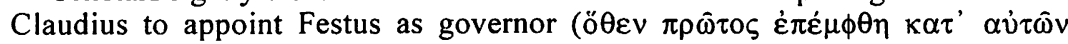
$\chi \imath \lambda i \alpha \rho \chi \circ \varsigma \Phi \hat{\eta} \sigma \tau \circ \zeta, 10.247)$ : so e.g. A.S. von Stauffenberg, Die Römische Kaisergeschichte bei Malalas: Griechischer Text der Bücher IX-XII und Untersuchungen, (Stuttgart: Kohlhammer, 1931), 200-202; Riesner, Paul's Early Period, 196. His statement might, however, be more apposite if one could assume a simple confusion of Felix and Festus: from the Roman perspective, Judaean mayhem under the disgraced Cumanus was (temporarily) subdued by the imposition of a firmer regime under Felix.

94 Cf. the subtitle of Schwartz, Agrippa I: The Last King of Judaea. 
were entrusted, that they all, as if by secret arrangement, systematically and deliberately set out to drive the people to revolt.'95

Things had begun to go wrong even under Ventidius Cumanus's two predecessors. Cuspius Fadus (AD 44-46), the first two of the new procurators, had his cavalry capture and kill the apocalyptic signprophet Theudas and several hundred of his followers (Ant. 20.97-99; cf. Acts 5:36). Fadus's successor, Philo of Alexandria's apostate nephew Tiberius Julius Alexander (AD 46-48), continued the clampdown against popular insurrectionist sentiment by personally ordering the crucifixion of James and Simon, the sons of Judas the Galilean (Ant. 20.102).96 During Alexander's tenure, the food supply of Jerusalem came to a severe crisis that for at least some of its inhabitants was alleviated only by the generosity of the newly converted Queen Helena of Adiabene. ${ }^{97}$ Famines, of course, had a high symbolic value in the ancient world and could serve as dark premonitions of impending judgement, a function they also exercise in the Jesus tradition. ${ }^{98}$ Judaea's intermittent crises of food supply between 44 and 49 are well attested and would have done much to encourage the apocalyptically inclined. ${ }^{99}$

95 Schürer/Vermes, A History of the Jewish People in the Age of Jesus Christ, 1.455. Cf. n. 111 below.

96 This policy might be thought in keeping with his later roles as governor of Egypt under Nero (AD 66-69: Josephus, War 2.309) and Titus's chief adviser during the siege of Jerusalem (Josephus, War 5.45-46, 510; 6.237-42; cf. Tacitus, Hist. 2.74). Cf. further Barclay, Jews in the Mediterranean Diaspora, 105-106.

97 See Ant. 20.101, 51. Luke's chronology in Acts 11:27-30 may nonetheless envisage the same famine: it may be that it is only Agabus' prophecy that follows the beginnings of the Antiochene Gentile mission among Stephen's dispersed followers (11:19-26), but predates Herod Agrippa's arrest of James (12:1). Luke's temporal references are in any case rather vague ( $\dot{\varepsilon} v \tau \alpha \hat{v} \tau \alpha \iota \varsigma \delta \dot{\varepsilon} \tau \alpha \hat{\imath} \zeta \dot{\eta} \mu \varepsilon \dot{\varepsilon} \rho \alpha \iota \zeta$,

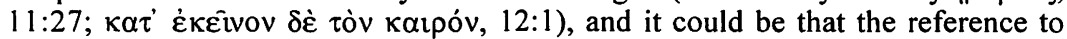
Claudius $(11: 28)$ does not envisage a famine in the years $41-44$, but is intended to highlight the Antioch church's charitable response to prophecy ahead of time. In practice we are not well placed to assess this matter: note Riesner's understated concession that 'it is not easy to evaluate with any historical accuracy the empirewide famine asserted in Acts 11:28' (Riesner, Paul's Early Period, 128). However, Riesner remains open to the possibility that Luke may be referring more generally to the series of local famines affecting many part of the empire throughout the $40 \mathrm{~s}$ (p. 131).

98 Mk. 13:8; Mt. 24:7; Lk. 21:11; cf. Rev. 18:8; 4 Ezra 15:5, 49; 16:18-22, 34-36. In Apoc. Abr. 30:5, 7, famine appears in the fourth and eighth of the ten plagues preceding the final eschatological judgement and conflagration.

99 For documentation see e.g. Schürer/Vermes, A History of the Jewish People in the Age of Jesus Christ, 1.457 n.8; Riesner, Paul's Early Period, 132-34. Talk of

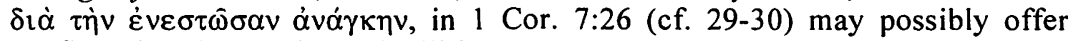
confirmation that Paul could still interpret contemporary crises in eschatological terms five years later. 


\section{c) A Second-Century Perspective}

Interestingly, the hindsight impression of an ominous turning point after the year 44 may find tenuous support in some Tannaitic references to 'King Agrippa' (who could in principle be either Agrippa I or Agrippa II). In most rabbinic texts, Agrippa appears as a man of demonstrative cultic observance who is well respected by the people, 100 an impression confirmed by both Philo and Josephus on Agrippa I. ${ }^{101}$ Strikingly, however, one Mishnah passage favourable to Agrippa is variously supplemented in the Tosefta and both Talmuds by a baraita involving two late second-century rabbis:

It was taught in the name of R. Nathan: at that hour the 'enemies of Israel' 102 were condemned to destruction because they flattered Agrippa (שהחניפו לו לאגריפס. R. Simeon ben Halafta said, From the day that the

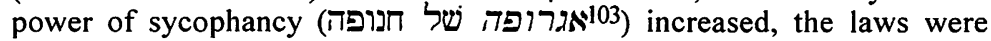
perverted and deeds corrupted; and no-one was able to say to his neighbour, 'My deeds are greater than yours.' 104

Without wishing to make much of this uncertain text, for our purposes it would suffice to see here another witness to the impression that the end of Agrippa's reign was long remembered as the beginning of a nasty turn in the fortunes of first-century Palestinian Judaism. 105 Paradoxically, this same impression is in fact underscored by the more typically idealising 106 view of Agrippa in the majority of rabbinic texts.

100 So e.g. m. Bik. 3.4 (par. t. Bik. 2.8; y. Bik. 3.4, 65b); m. Sotah 7.6 (par. t. Sotah 7.8; y. Sotah 7.7, 22a; b. Sotah 40b-41a); cf. t. Pesah. 4.15; y. Š eqal. 5.2, 48d; Sipre Deut.157.3; Lev. R. 3.5 (1.17).

101 See e.g. Josephus's favourable description in Ant. 19.328-34; cf. also Philo Flacc. 27-28, 30, 103 for Agrippa's enthusiastic welcome by the Jews of Alexandria as early as $A D$ 38, when he was returning from Rome to take up his new kingdom in northern Palestine. Cf. Barclay, Jews in the Mediterranean Diaspora, 52, 295 on the latter incident.

102 שוניאי ישוֹראי: a common critical euphemism for Israel (when misguided or rebellious).

${ }^{103}$ Quite possibly an intentional pun to link with an originally independent tradition (so also Schwartz, Agrippa I: The Last King of Judaea, $171 \mathrm{n} .89$, citing R. Edels and J.M. Baumgarten).

${ }^{104}$ B. Sotah 41 b; cf. t. Sotah 7.16.

${ }^{105}$ For a more agnostic view of this tradition see Schwartz, Agrippa I: The Last King of Judaea, 160-62, although his summary on pp. 170-71 seems more sanguine.

106 Agrippa's activities outside Jerusalem certainly cast doubt on the sincerity of his Jewish devotion. Like his grandfather Herod, he pursued grand architectural schemes that made no secret of his love of Graeco-Roman culture. Thus, he constructed a theatre, amphitheatre, baths and porticoes at Berytus (Beirut), where he also sponsored games and spectacles including a gladiatorial display in which 1,400 criminals were compelled to slaughter each other (Ant. 19.335-37). He 


\section{d) A Note on the Edict of Claudius}

Before concluding, we must make reference to one other serious blow dealt to Jewish life in the year 49, namely the famous Edict of Claudius ordering an expulsion of Jews from Rome.107 Detailed discussion of this Edict may safely be left to those more expert in this matter; a brief comment, however, is appropriate in view of the fact that it has sometimes been adduced in connection with 1 Thessalonians 2:16c. 108

There are at least three reasons to caution against the assumption of any deliberate reference to the Claudius Edict in this verse. (1) This edict had a tangibly, if not indeed disproportionately, adverse effect on the Christian community at Rome too, and so could hardly serve as a clear demonstration of God's wrath against the persecutors. (2) It affected Rome and not Judaea. (3) It is unclear if Paul knew of it at the time of writing. He did of course meet Prisca and Aquila in Corinth after their expulsion from Rome (Acts 18:2); but a relatively early date of 1 Thessalonians, as proposed above, would agree well with the fact that this letter does not as yet show signs of any specific awareness of such measures. 109

\section{Conclusion}

We began by re-examining the evidence for a post-70 interpolation at 1 Thessalonians 2:14-16, and found that, despite some intrinsic

erected statues of his daughters at Caesarea (Ant. 19.357), and minted coins picturing the pigs used in sacrifices in the temple of Jupiter Capitolinus (see Ibid., 131 and $\mathrm{n}$. 97). His official designation included the stereotypical, but in this context no less striking epithets 'friend of Caesar' (cf. Jn. 19:12) and 'friend of the

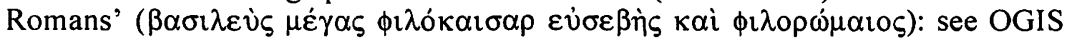
419, discussed in Schürer/Vermes, A History of the Jewish People in the Age of Jesus Christ, 1.452.

${ }^{107}$ Suetonius, Claudius 25.4; cf. Acts 18:2. The two most detailed recent chronological studies, Riesner, Paul's Early Period, 157-201 and H. Botermann, Das Judenedikt des Kaisers Claudius: Römischer Staat und Christiani im 1. Jahrhundert (Hermes Einzelschriften 71; Stuttgart: F. Steiner, 1996), 44-140 and passim, both resolve the chronological problems clearly in favour of dating the Edict in AD 49. Cf. also Barclay, Jews in the Mediterranean Diaspora, 303-306.

108 So e.g. Bammel, 'Judenverfolgung und Naherwartung', 295-301, 306; Best, Commentary, 120; also P. Schmidt, Der erste Thessalonicherbrief neu erklärt: nebst einem Excurs über den zweiten gleichnamigen Brief (Berlin: Georg Reimer, 1885), 87-90, cited in Bammel, 'Judenverfolgung und Naherwartung', 306 and Légasse, 'Paul et les Juifs d'après 1 Thessaloniciens 2,13-16', 586 n.54.

109 Unless there is a hint in 2:18; but I think not. 
attractions, the case remains unconvincing. Assuming, therefore, the authenticity of Paul's harsh words about the perpetrators of Christian suffering in Judaea, the second part of the paper attempted to assess the difficult question of their likely historical setting. Given the tone and substance of Paul's reference to apparently current events, what would be needed is a credible correlation between significant and recent persecution and a consequent ominous downturn in Jewish fortunes. My proposal is to set alongside the scattered evidence in Galatians the suggestion in Malalas of a persecution of the Jerusalem Christians in the year $48 / 49$, which would add to previous measures taken against them in the mid-30s and again after Agrippa's accession in 41 . This third persecution would be relatively easy to accommodate around the proposed date, and might in turn shed light on the setting of 1 Thessalonians and Galatians (and perhaps of certain passages in Acts). ${ }^{110}$

As for Paul's reference to divine wrath, the scheme here proposed suggests attention to the violent upheavals suffered in Judaea most recently under its inept new procurator Ventidius Cumanus, and more generally to the sense, attested in a number of Jewish texts, that the violent and famished years after the death of Agrippa constituted a grave decline in Jewish fortunes. To this position, well attested in older scholarship but lately neglected, ${ }^{111}$ may be added the observation that even after more than a century had passed, some rabbis would still regard Agrippa's reign as the beginning of the road to destruction.

All this renders Paul's comments in 1 Thessalonians 2 remarkably intelligible on the historical level, much as their unhappy effective history may make us wish that he had not made them. Their reception by a Gentile rather than a Jewish readership must surely hasten and harden the perception of a parting of the ways between Jews and Christians. ${ }^{112}$ Nevertheless, interpreted within the theological

\footnotetext{
${ }^{110}$ See above, p. 24.

111 Using some of the same texts we adduced from Josephus, Grimm, 'Die Echtheit der Briefe an die Thessalonicher', 774 already offered a very similar conclusion a century and a half ago: 'Der Apostel erblickt in den damaligen gedrückten politischen Verhältnissen Palästina's den Beginn des göttlichen Strafgerichts, den Anfang der Entwickelung zur endlichen Katastrophe, nach der apostolischen Grundansicht, daß die letzte Zeit (o Ě $\sigma \chi \alpha \tau o \varsigma \kappa \alpha i \rho \circ \varsigma)$ und mit ihr die Offenbarung des göttlichen Zorns schon da sey.... Es brachen von nun an über das Volk Stürme und Unglücksfälle herein, deren ununterbrochene Kette im völligen Untergange des Staates endigte.'

112 It is, nevertheless, significant to note that this passage did not feature prominently in later Christian adversus Iudaeos literature. See R. Kampling, 'Eine
} 
framework of the day, the 'signs of the times' did not manifestly discourage judgements such as his.

Further inquiry would certainly need to address the question of this passage's Thessalonian setting, to which we alluded at the beginning. Meanwhile, one of the wider implications of this more specialised inquiry may be its confirmation of the significant but frequently hidden extent to which the present and future fate of Jerusalem continued to weigh on Paul's mind, and to shape his thought, from the earliest to the latest of his letters to Gentile churches. ${ }^{113}$

auslegungsgeschichtliche Skizze zu 1 Thess 2,14-16', in Begegnungen zwischen Christentum und Judentum in Antike und Mittelalter: Festschrift für Heinz Schreckenberg, eds. D.-A. Koch \& H. Lichtenberger (Schriften des Institutum Judaicum Delitzschianum 1; Göttingen: Vandenhoeck \& Ruprecht, 1993), 183213.

113 On this subject, classically advocated by scholars such as J. Munck, Paul and the Salvation of Mankind (London: SCM, 1959), cf. e.g. recently W. Horbury, 'Land, Sanctuary and Worship', in Early Christian Thought in Its Jewish Context, eds. J.M.G. Barclay \& J. Sweet (Cambridge: CUP, 1996), 207-24, esp. 219-22. Contrast writers like Walker, Jesus and the Holy City, e.g. 116-19, 144-51; and see n. 40 above. In addition to passages like Gal. 4:25, 29; 6:12, 16 and Rom. 15:31 cited earlier, see above all Rom. 9:4-5, 33; 11:25-29; 15:16, 19, 25-27; also 1 Cor. $16: 1,8 ; 2$ Cor. 8:4, 14; $9: 1$. Note further the expectation of the Antichrist's

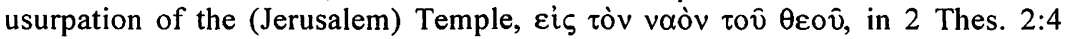
(whether authentic or not). Even passages like Eph. 2:14-15, 19-21 make sense only as a variation on this theme. 